\title{
Evidence for protein oedema, neutrophil influx, and enhanced collagen production in lungs of patients with systemic sclerosis
}

\author{
N K Harrison, R J McAnulty, P L Haslam, C M Black, G J Laurent
}

\begin{abstract}
Bronchoalveolar lavage fluid from patients with systemic sclerosis was analysed for evidence of pulmonary vascular leakage, inflammatory cell influx, and enhanced type III collagen synthesis. Eighteen patients with systemic sclerosis and computed tomographic evidence of fibrosing alveolitis were compared with 16 patients with a normal scan. The albumin concentration in lavage fluid was higher in all patients than in normal volunteers. Patients with an abnormal computed tomogram as a group had increased proportions of all inflammatory cell types, whereas those with a normal scan had increased neutrophils only. Increased lavage type III procollagen peptides were found in all patients with an abnormal computed tomogram and eight of those with a normal scan. These results suggest that pulmonary vascular leakage and neutrophil influx may be early pathological features of lung disease in systemic sclerosis and frequently associated with enhanced collagen production. Thus lavage of patients with systemic sclerosis may identify lung inflammation and altered collagen metabolism early in the evolution of fibrosing alveolitis.
\end{abstract}

Systemic sclerosis is characterised by a vascular disorder and excessive deposition of collagen and other matrix proteins in the skin and internal organs. ${ }^{1}$ Symptoms and signs of lung disease are rare when patients first present, yet up to $80 \%$ have abnormal lungs at necropsy. ${ }^{23}$ The histological appearances are identical to those of cryptogenic fibrosing alveolitis. ${ }^{4}$ The investigation of patients with systemic sclerosis offers an opportunity therefore to study fibrosing alveolitis from the earliest stages of its evolution.

Symptomless patients with collagen vascular disorders, including a few with systemic sclerosis, have evidence of subclinical alveolitis. ${ }^{5}$ There are, however, currently no data to indicate whether this alveolitis is associated with other pathological processes, such as pulmonary vascular leakage of plasma proteins or altered lung collagen metabolism.

The aim of this study was to examine the lower respiratory tract of patients with systemic sclerosis for evidence of pulmonary vas- cular leakage, inflammatory cell infiltration, and enhanced lung collagen metabolism.

\section{Methods}

PATIENTS

We investigated 34 patients fulfilling the American Rheumatism Association's preliminary criteria for the diagnosis of systemic sclerosis. ${ }^{6}$ All underwent clinical evaluation, including chest radiography, lung function tests, thin ( $3 \mathrm{~mm}$ ) section thoracic computed tomography, ${ }^{7}$ and liver and renal function tests. The clinical data are summarised in table 1. Patients were divided into those with and those without computed tomographic evidence of fibrosing alveolitis. ${ }^{8}$ Each scan was assessed by a radiologist who was unaware of the patient's clinical condition.

BRONCHOALVEOLAR LAVAGE

All patients underwent. fibreoptic bronchoscopy and bronchoalveolar lavage. ${ }^{9}$ Lavage fluid was collected in a siliconised container on ice, and all subsequent manipulations were performed at $4^{\circ} \mathrm{C}$ to minimise protein degradation during processing. Lavage was also performed on 10 healthy, non-smoking volunteers who acted as controls. The median age of the control group was 29 (range 21-36) years.

Lavage fluid was centrifuged at $300 \mathrm{~g}$ for five minutes, and the supernatant stored at $-40^{\circ} \mathrm{C}$. The cell pellet was resuspended and the total and differential cell count determined immediately. ${ }^{9}$ Blood was collected from all subjects at the time of bronchoscopy and serum stored at $-40^{\circ} \mathrm{C}$. Albumin concentrations were measured calorimetrically in $20 \mu \mathrm{l}$ aliquots of serum and $1 \mathrm{ml}$ aliquots of unconcentrated lavage fluid, the Bromocresol Green binding reaction being used (Sigma Chemical Company, Poole, Dorset).

\section{TYPE III PROCOLLAGEN $N$ PEPTIDE ASSAY}

Bronchoalveolar lavage fluid was concentrated by dialysing it extensively against an aqueous solution of $0.02 \mathrm{M}$ ammonium bicarbonate at $4^{\circ} \mathrm{C}$ with a molecular weight cut off of 2000 (Sigma Chemical Company). Known volumes $(1.25-2.5 \mathrm{ml})$ were then lyophylised in $3.5 \mathrm{ml}$ polystyrene test tubes (Sarstedt, West Germany) and redissolved in phosphate buffered saline containing $0.4 \mathrm{~g} / 1$ Tween 20 to give $50-100$ fold concentrates. Duplicate samples of concentrated lavage fluids and $25 \mu \mathrm{l}$ 
Table 1 Clinical, radiographic, and physiological characteristics of 34 patients with systemic sclerosis (medians and ranges unless otherwise specified)

\begin{tabular}{|c|c|c|c|c|c|c|c|}
\hline \multirow{3}{*}{$\begin{array}{l}\text { Group } \\
\text { CT abnormal } \\
\text { CT normal }\end{array}$} & \multirow[b]{2}{*}{ Age (y) } & \multirow{2}{*}{$\begin{array}{l}\text { Duration (y) } \\
\text { of } \\
\text { systemic } \\
\text { sclerosis }\end{array}$} & \multirow{3}{*}{$\begin{array}{l}\begin{array}{l}\text { Smoking } \\
\text { habit } \\
(N S: S)\end{array} \\
18: 0 \\
13: 3\end{array}$} & \multirow{3}{*}{$\begin{array}{l}\text { Radiograph } \\
(N: A b n) \\
\begin{array}{c}4: 14 \\
16: 0\end{array}\end{array}$} & \multicolumn{3}{|c|}{ Lung function tests } \\
\hline & & & & & $\begin{array}{l}F V C \\
\text { (\% pred) }\end{array}$ & $\begin{array}{l}\text { TLCO } \\
\text { (\% pred) }\end{array}$ & $\begin{array}{l}\text { Exercise } \\
A-a D o_{2}(k P a)\end{array}$ \\
\hline & $\begin{array}{ll}47 \quad(24-62) \\
49 \cdot 5(31-64)\end{array}$ & $\begin{array}{l}7(1-16) \\
3 *(1-16)\end{array}$ & & & $\begin{array}{ll}75 & (47-106) \\
99 \star \star & (81-112)\end{array}$ & $\begin{array}{ll}52 & (37-80) \\
76^{\star \star} & (54-104)\end{array}$ & $\begin{array}{l}3.6(1.9-8.5) \\
2.4(1.2-3.6)\end{array}$ \\
\hline
\end{tabular}

${ }^{\star} \mathrm{p}<0.05 ;{ }^{\star \star} \mathrm{p}<0.01$

CT—computed tomogram; NS:S—non-smokers:smokers; N:Abn-normal:abnormal; FVC—forced vital capacity; TLco-carbon monoxide transfer factor; $\mathrm{A}-\mathrm{aDO}_{2}$-alveolar-arterial oxygen tension difference.

Table 2 Characteristics of lavage fluid from patients with scleroderma

\begin{tabular}{lllll}
\hline Group & $\begin{array}{l}\text { Lavage fluid } \\
(\% \text { recovered })\end{array}$ & $\begin{array}{l}\text { Albumin } \\
(\mathrm{mg} / \mathrm{ml})\end{array}$ & $\begin{array}{l}\text { BALF:serum } \\
\text { albumin ratio } \\
\left(\times 10^{3}\right)\end{array}$ & $\begin{array}{l}\text { Total cells } \\
\left(\times 10^{-6}\right)\end{array}$ \\
\hline $\begin{array}{l}\text { Controls }(\mathrm{n}=10) \\
\text { Patients: }\end{array}$ & $63(32-79)$ & $0.04(0 \cdot 027-0 \cdot 09)$ & $1 \cdot 45(0 \cdot 6-1 \cdot 37)$ & $12 \cdot 2(4 \cdot 4-21 \cdot 7)$ \\
$\begin{array}{l}\text { CT abnormal }(\mathrm{n}=18) \\
\text { CT normal }(\mathrm{n}=16)\end{array}$ & $42(19-56)$ & $\begin{array}{l}0.23^{\star}(0 \cdot 1-0.36) \\
0.19^{\star}(0 \cdot 1-0 \cdot 32)\end{array}$ & $\begin{array}{l}7 \cdot 3^{\star}(2 \cdot 9-11 \cdot 6) \\
5 \cdot 75^{\star}(2 \cdot 8-9 \cdot 1)\end{array}$ & $\begin{array}{l}17 \cdot 7(6 \cdot 2-48) \\
11 \cdot 5(3 \cdot 0-39)\end{array}$ \\
\hline
\end{tabular}

${ }^{\star} \mathrm{p}<0.01$ in the comparison with controls.

CT-computed tomogram; BALF-bronchoalveolar lavage fluid.

aliquots of serum were assayed for antigens related to type III procollagen $N$ terminal peptide by a commercially available radioimmunoassay (Hoechst, West Germany), which uses Fab fragments of antibody to the peptide. ${ }^{10}$ Serial dilutions of an unlabelled procollagen $N$ peptide standard were assayed in triplicate and used to construct an inhibition curve. The Fab fragments have equal affinity for the different antigenic forms of the peptide that occur in biological fluids, and therefore inhibition curves generated by serial dilutions of such fluids parallel those generated by dilutions of the standard. ${ }^{10}$

\section{STATISTICS}

Group data of non-parametric variables are expressed as medians with ranges and com- pared by the Mann-Whitney U test. Correlations were assessed with Kendall's rank correlation coefficient.

\section{Results}

LAVAGE FLUID ALBUMIN AND CELLULARITY

The albumin concentrations in both groups of patients with systemic sclerosis were significantly greater than those from control subjects, when values were expressed both as absolute amounts and as lavage fluid: serum ratios (table 2). The total number of cells recovered from each subject varied considerably and no differences between the groups were observed (table 2). The differential cell counts show that patients with an abnormal computed tomogram had higher proportions of
Figure 1 Inflammatory
cell profiles $(\%$ total cell count) in patients with systemic sclerosis. CT-computed tomogram.

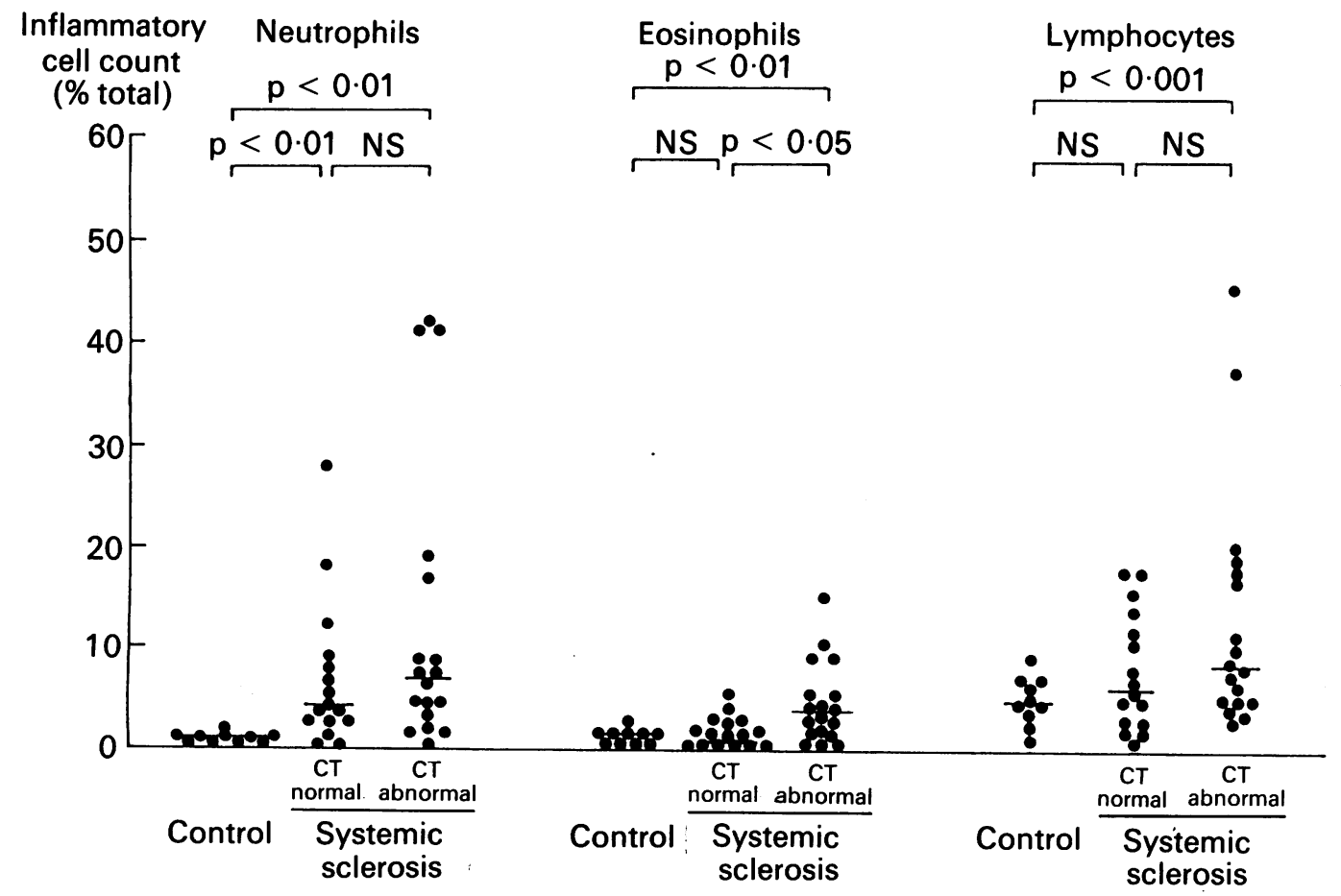




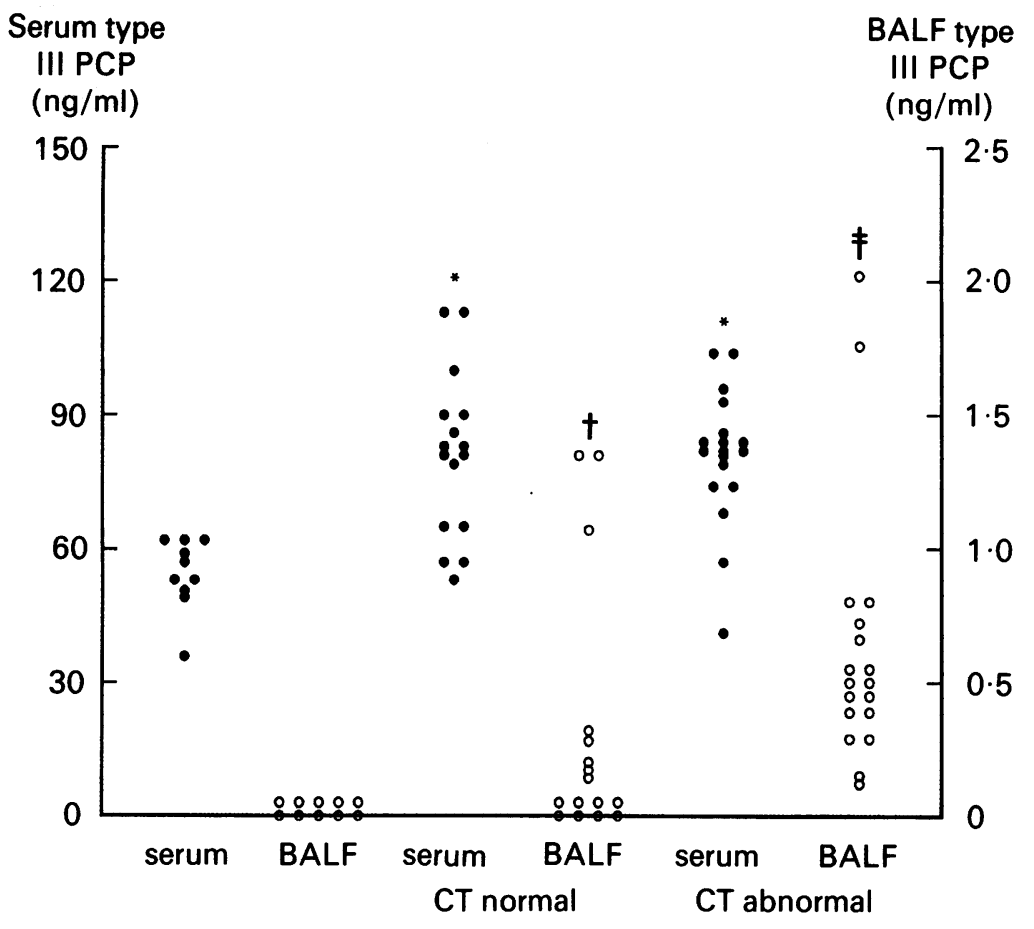

CONTROL

\section{SYSTEMIC SCLEROSIS}

Figure 2 Type III procollagen $N$ terminal peptides in serum (O) and bronchoalveolar lavage fluid (BALF: O) from 34 patients with systemic sclerosis and 10 healthy volunteers. ${ }^{*} p<0.01$ controls; $t_{p}<0.02$, both in the comparison with controls; $\pm p<0.02$ in the comparison with patients with normal computed tomograms. PCP-procollagen peptides; $C T$-computed tomogram. bon monoxide transfer and those in whom it was normal.

When serum and lavage fluid concentrations of procollagen $N$ peptide were corrected for albumin concentration they showed trends similar to those shown in figure 2 , but lavage fluid concentrations in the patients often exceeded those in corresponding serum. The mean procollagen $N$ peptide concentrations in lavage fluid in the patients with computed tomographic evidence of fibrosing alveolitis were two to three times greater than the concentrations in patients without evidence of lung disease $(p<0.001)$. Concentrations of procollagen $N$ peptide in lavage fluid did not correlate with the duration of systemic sclerosis, results of physiological tests of lung function, lavage fluid albumin concentration, or inflammatory cell counts in lavage fluid.

\section{Discussion}

Raised concentrations of albumin were found in the lavage fluid from all patients, irrespective of whether there was clinical evidence of pulmonary fibrosis. This suggests that increased pulmonary vascular leakage may be one of the earliest abnormalities of lung disease in systemic sclerosis and can be detected by bronchoalveolar lavage. This observation is consistent with findings from studies in experimental animals, where vascular leakage is detectable many days before pulmonary fibrosis is apparent biochemically or histologically. ${ }^{11-14}$ The relevance of increased vascular permeability to the pathogenesis of pulmonary fibrosis is uncertain, but could indicate loss of endothelial integrity, allowing leakage of circulating blood proteins, inflammatory cells, or platelets from the circulation into the lung interstitium. These could provide a rich source of mediators capable of promoting lung collagen production by stimulating either fibroblast proliferation ${ }^{15-17}$ or collagen production by individual fibroblasts. ${ }^{18}$

Lavage fluid cell counts in our study showed that patients with systemic sclerosis and evidence of fibrosing alveolitis as a group had higher proportions of neutrophils, eosinophils, and lymphocytes than control subjects, confirming earlier reports. ${ }^{19-21}$ Patients without evidence of fibrosing alveolitis had increased proportions of neutrophils alone, even when the smokers were excluded. This agrees with an earlier report of increased neutrophils in the lavage fluid of six of 10 patients with systemic sclerosis and normal chest radiograph and normal lung function. ${ }^{5}$ These observations suggest that neutrophil alveolitis is an early event in the pathogenesis of lung disease in systemic sclerosis, though analysis of lavage fluid may not reflect changes in the interstitium, where infiltration by other inflammatory cells, such as lymphocytes, may occur. ${ }^{4}$

There is currently no direct information on in vivo collagen production by the human lung, though several indirect techniques have been applied to the study of patients with fibrotic lung disorders. In general, these have been either measurements of post-translational patients with a normal scan. In those normal scan there was no statistical difference in procollagen $N$ peptide concentrations in lavage fluid between those with impaired car- 
processing of procollagen molecules ${ }^{22}$ or the enzymes concerned in this process. ${ }^{23}$

The serum procollagen $N$ peptide concentrations we found are similar to those previously reported for both normal volunteers ${ }^{25}$ and patients with systemic sclerosis. ${ }^{26}$ Our results indicate that the measurement of serum procollagen $N$ peptide does not distinguish patients with clinical evidence of pulmonary fibrosis from those without. By contrast, our results for bronchoalveolar lavage fluid suggest a progressive increase in type III collagen synthesis with the development of pulmonary fibrosis, though these data do not necessarily indicate that type III collagen is laid down as mature collagen fibrils in the lung interstitium. Nevertheless, our results complement those of previous morphometric ${ }^{27}$ and biochemical ${ }^{28} 29$ studies, in which an increased lung collagen content was found in fibrosing alveolitis.

The lack of correlation between procollagen $N$ peptide concentrations in lavage fluid and results of physiological tests of lung function requires explanation. Our data could mean that raised procollagen $N$ peptide concentrations in lavage fluid, and by implication increased type III collagen synthesis by the lung, may occur very early in the pathogenesis of pulmonary fibrosis, at a stage undetectable by conventional techniques, including computed tomography of the thorax. It has been suggested that in areas of established pulmonary fibrosis type III collagen tends to be replaced by type I collagen $^{27}$; in the patients with advanced lung disease therefore lavage fluid procollagen $N$ peptide might be expected to return to more modest levels.

Our observations suggest increased pulmonary vascular permeability in patients with systemic sclerosis and concentrations of procollagen $N$ peptide in lavage fluid might reflect leakage of these antigens from the circulation. There is evidence to refute this proposal, however. There was no correlation between albumin and procollagen $N$ peptide in lavage fluid and an appreciable number of patients had a concentration of the peptide in their lavage fluid which, in relation to the albumin concentration, still greatly exceeded the level in their serum. This suggests enhanced type III collagen production by the lungs.

Increased concentrations of procollagen $N$ peptide in bronchoalveolar lavage fluid from patients with other interstitial lung diseases have been reported, ${ }^{22} 30-32$ but this is the first study of pulmonary disease in systemic sclerosis. All previous studies were based on a radioimmunoassay using whole IgG antiprocollagen $N$ peptide. ${ }^{33}$ Although this assay is very sensitive, it preferentially measures the Col 1-3 antigen. Type III procollagen peptides in lavage fluid may occur in several different antigenic forms $\mathrm{s}^{34}$ and the assay using whole antibody may be less appropriate for use on lavage fluid, though it is the Col 1-3 peptide that probably reflects collagen synthesis most accurately. Despite differences in the assays, data from the present and previous studies suggest that procollagen peptides in lavage fluid reflect altered type III collagen metabolism of the lung interstitium in vivo.
This study suggests that increased pulmonary vascular leakage and neutrophil alveolitis may be early features of interstitial lung disease in systemic sclerosis and that these abnormalities are frequently associated with evidence of enhanced lung type III collagen synthesis. Possibly these inflammatory changes could resolve in some patients without the development of lung fibrosis. These findings are likely to be relevant to the early clinical diagnosis of pulmonary fibrosis and to investigators interested in understanding its pathogenesis.

We wish to thank Professor Margaret Turner-Warwick for her encouragement and for the clinical management of patients in this study, and Astrid Greenberry for typing the manuscript. This work was supported by a grant from the Arthritis and Rheumatism Council of Great Britain and the Wellcome Trust.

1 LeRoy EC. Scleroderma (systemic sclerosis). In: Kelly ED, Harris ED, eds. Textbook of rheumatology. Philadelphia: Saunders, 1981:1211-30.

2 Weaver AL, Divertie MD, Titus JL. Pulmonary scleroderma. Dis Chest 1968;54:490-8.

3 D'Angelo WA, Fries JF, Masi AT, Schulman LE. Pathologic observations in systemic sclerosis (scleroderma). Am $J$ Med 1969;46:428-40.

4 Harrison NK, Glanville AR, Strickland B, et al. Pulmonary involvement in systemic sclerosis: the detection of early disease by thin section CT scan, bronchoalveolar lavage and ${ }^{99_{m}}$ Tc-DTPA clearance. Respir Med 1989;83:403-14.

5 Wallaert B, Hatron PY, Grosbois JM, Tonnel AB, Devulder $B$, Voison C. Subclinical pulmonary involvement in collagen vascular disease assessed by bronchoalveolar lavage. Am Rev Respir Dis 1986;33:574-80.

6 Medsger TA. Comment on Scleroderma criteria. In: Black CM, Myers AR, eds. Current topics in rheumatology: CM, Myers AR, eds. Current topics in rheumatology:
systemic sclerosis (scleroderma). New York: Gower, 1986.

7 Strickland B, Brennan J, Dennison DM. Computed tomography in lung disease: Improving the image. Clin Radiol 1986;37:335-8.

8 Strickland B. Imaging fibrosing alveolitis. Postgrad Med J 1988;4(suppl 4):35-40.

9 Haslam PL, Turton CWG, Lukoszek A, et al. Bronchoalveolar lavage fluid cell counts in cryptogenic fibrosing alveolitis and their relation to therapy. Thorax 1980; 33:328-39.

10 Rohde H, Langer I, Krieg T, Timpl R. Serum and urine analysis of the aminoterminal procollagen peptide type III by radioimmunoassay with antibody FAB fragments. Coll by radioimmunoassay
Rel Res $1983 ; 3: 371-9$.

11 Thrall RS, McCormick JR, Jack RM, McReynolds RA, Ward PA. Bleomycin-induced pulmonary fibrosis in the rat. Inhibition by indomethacin. Am J Pathol 1979;95: 117-30.

12 Wangensteen D, Yankovich R, Hoidal J, Niewoehner D. Bleomycin-induced changes in pulmonary microvascular albumin permeability and extravascular albumin space. Am Rev Respir Dis 1983;127:204-8.

13 Hay JG, Haslam PL, Dewar A, Addis B, Turner-Warwick $M$, Laurent GJ. Development of acute lung injury after the combination of intravenous bleomycin and exposure to hyperoxia in rats. Thorax 1987;42:374-82.

14 Hesterberg TW, Gerriets JE, Reiser KM, Jackson AC, Cross CE, Last JA. Bleomycin-induced pulmonary fibrosis: Correlation of biochemical, physiological and histological changes. Toxicol Appl Pharmacol 1981;60: 360-7.

15 Bitterman PB, Rennard SI, Hunninghake GW, Crystal RG Human alveolar macrophage growth factor for fibroblasts. J Clin Invest 1982;70:806-22.

16 Martinet Y, Rom WN, Grotendorst GR, Martin GR, Crystal RG. Exaggerated spontaneous release of plateletderived growth factor by alveolar macrophages from patients with idiopathic pulmonary fibrosis. N Engl J Med 1987;317:202-9.

17 Postlethwaite AE, Kang AH. Characterisation of fibroblast proliferation factors elaborated by antigen- and mitogenproliferation factors elaborated by antigen- and mitogenfrom lymphocyte-derived chemotactic factors for fibrofrom lymphocyte-derived chemotactic factors for fibro-
blasts, lymphocyte mitogenic factor, and interleukin 1 . blasts, lymphocyte mitogenic

18 Fine A, Goldstein RH. The effect of transforming growth factor- $\beta$ on cell proliferation and collagen formation by lung fibroblasts. J Biol Chem 1987;262:3897-902.

19 Rossi GA, Bitterman PB, Rennard SI, Ferrans VJ, Crystal RG. Evidence for chronic inflammation as a component of the interstitial lung disease associated with progressive systemic sclerosis. Am Rev Respir Dis 1985;131:612-7.

20 Konig G, Luderschmidt C, Hammer C, Adelmann-Gril BC, Braun-Falco O, Fruhmann G. Lung involvement in scleroderma. Chest 1984;855:318-24.

21 Silver RM, Metcalf JF, Stanley JH, LeRoy EC. Interstitial lung disease in scleroderma: analysis by bronchoalveolar lavage. Arth Rheum 1984;27:1254-62. 
22 Low RB, Cutroneo KR, Davis GS, Giancola BS. Lavage type III procollagen $N$-terminal peptides in human pulmonary fibrosis and sarcoidosis. Lab Invest 1983;48: 755-9.

23 Breul SD, Bradley KH, Hance AH, Schafer M, Berg RA, Crystal RG. Control of collagen production by human diploid lung fibroblasts. J Biol Chem 1980;255:5250-60.

24 Risteli L, Risteli J. Non-invasive methods for detection of organ fibrosis. In: Rojkind M, ed. Focus on connective tissue in health and disease. Boca Ratton, Florida: CRC Press (in press).

25 Bentsen KD, Horslev-Petersen $K$, Junker P, Juhl E, Lorenzen I. Serum aminoterminal procollagen type III peptide in acute viral hepatitis. A long-term follow-up study. Liver 1987

26 Majewski S, Skiendzielewska A, Makiela B, Jablonska S, Blaszczyk M. Serum levels of type III collagen aminopropeptide in patients with systemic sclerosis. Arch Dermatol Res 1987;279:484-6.

27 Bateman ED, Turner-Warwick M, Haslam P, AdelmanGrill BC. Cryptogenic fibrosing alveolitis: prediction of fibrogenic activity from immunohistochemical studies of collagen types in lung biopsy specimens. Thorax 1983; 38:93-101.

28 Kirk JME, DaCosta PE, Turner-Warwick M, Littlejohn RJ Laurent GJ. Biochemical evidence for an increased and progressive deposition of collagen in the lungs of patients with pulmonary fibrosis. Clin Sci 1986;70:39-45.

29 Selman M, Montano M, Ramos C, Chapale R. Concentration, biosynthesis and degradation of collagen in idiopathic pulmonary fibrosis. Thorax 1986;41:355-59.

30 Bjermer $L$, Thunell M, Hallgren $R$. Procollagen III peptide in bronchoalveolar lavage fluid: a potential marker of altered collagen synthesis reflecting pulmonary disease in sarcoidosis. Lab Invest 1985;55:654-6.

31 Bjermer L. Engstrom-Laurent A, Lundgren R, Rosenthall L, Hallgren R. Hyaluronate and type III procollagen peptide in bronchoalveolar lavage fluid as markers of disease activity in farmers lung. Br Med J 1987;295:803-6.

32 Bjermer $L$, Lundgren $R$, Hallgren $R$. Hyaluron and type III procollagen peptide concentrations in bronchoalveolar procollagen peptide concentrations in bronchoalveolar
lavage fluid in idiopathic pulmonary fibrosis. Thorax lavage fluid in idio

33 Rohde H, Vargas L, Hahn E, Kalbfleisch H, Bruguera M, Timpl R. Radioimmunoassay for type III procollagen peptide and its application to human liver disease. Eur $J$ Clin Invest 1979;9:451-9.

34 Harrison NK, McAnulty RJ, Argent AC, Black CM, Turner-Warwick $M$. Antigenic forms of type III procollagen $N$-terminal peptides in serum and bronchoalveolar lavage fluid from patients with systemic sclerosis [abstract]. Am Rev Respir Dis 1989;139:A204. 